Research Paper

\title{
Gynostemma pentaphyllum saponins attenuate inflammation in vitro and in vivo by inhibition of NF-KB and STAT3 signaling
}

\author{
Wing-Yan Wong ${ }^{1, *}$, Magnolia Muk-Lan Lee ${ }^{1, *}$, Brandon Dow Chan ${ }^{1, *}$, Victor Wan- \\ San $\mathrm{Ma}^{3}$, Wenchun Zhang ${ }^{2}$, Timothy Tak-Chun Yip ${ }^{3}$, Wing-Tak Wong ${ }^{1}$ and William \\ Chi-Shing Tai ${ }^{1,2}$ \\ ${ }^{1}$ Department of Applied Biology and Chemical Technology, The Hong Kong Polytechnic University, Hong Kong S.A.R., China \\ ${ }^{2}$ State Key Laboratory of Chinese Medicine and Molecular Pharmacology (Incubation), Shenzhen Research Institute of The \\ Hong Kong Polytechnic University, Shenzhen, China \\ ${ }^{3}$ Department of Clinical Oncology, Queen Elizabeth Hospital, Hong Kong S.A.R., China \\ *These authors contributed equally to this work
}

Correspondence to: William Chi-Shing Tai, email: william-cs.tai@polyu.edu.hk

Keywords: gynostemma pentaphyllum saponins, inflammatory bowel disease, macrophages, colitis, anti-inflammation

Received: May 24, $2017 \quad$ Accepted: August 29, $2017 \quad$ Published: September 18, 2017

Copyright: Wong et al. This is an open-access article distributed under the terms of the Creative Commons Attribution License 3.0 (CC BY 3.0), which permits unrestricted use, distribution, and reproduction in any medium, provided the original author and source are credited.

\section{ABSTRACT}

Recent advances in the development of anti-inflammatory agents have improved their therapeutic outcome in inflammatory bowel disease (IBD), however, the presence of side effects and limited effectiveness hinder their widespread use. Therefore, novel compounds with strong anti-inflammatory efficacy are still required. In this study, we investigated the anti-inflammatory effect and potential mechanisms of Gynostemma pentaphyllum (Thunb.) Makino saponins (GpS), a major component of the herbal medicine widely used in Asian countries. In in vitro studies, we demonstrated that GpS dose dependently suppressed activation of macrophages, one of the main effectors in IBD. GpS also suppressed cytokine production and the activation of NF-KB and STAT3 signaling in lipopolysaccharide-induced macrophages, without affecting their viability. Further in vivo studies demonstrated that GpS could ameliorate the weight loss, increased disease activity index, colon shortening and histological damage associated with dextran sulfate sodium (DSS)-induced colitis in mice. In agreement with results from our in vitro experiments, GpS suppressed cytokine production and activation of NF-KB and STAT3 signaling in the colons of DSS-induced mice.

In this study, we present for the first time, evidence of the therapeutic effect of GpS in IBD, highlighting its potential as an effective therapeutic against the disease.

\section{INTRODUCTION}

Inflammatory bowel disease (IBD) is a chronic, relapsing gastrointestinal inflammatory disorder comprising as its two major forms, ulcerative colitis (UC) and Crohn's disease (CD). It is estimated that over 3.7 million people worldwide suffer from IBD, and incidence and prevalence rates continue to increase. North America and Western Europe are traditionally regarded as high risk areas for IBD, however, emerging populations such as those in Asia have exhibited rapid increases in the prevalence of IBD over the past several decades. Although the exact etiology of IBD requires further study, interactions between causal factors for the disease - environment, host genetics, immune system and microbiome - are known to be important $[1,2]$. In particular, a dysregulated immune system has been acknowledged to be a major contributor to the pathogenesis and progression of IBD $[3,4]$.

In the pathogenesis of IBD, intestinal immune homeostasis is disturbed, resulting in uncontrolled activation of innate and adaptive immune cells. Macrophages are one of the most abundant innate immune cell types in the intestine and play a key role in 
the pathogenesis of IBD $[5,6]$. In the active state of the disease, macrophages in the intestine are activated and respond by releasing proinflammatory cytokines such as inducible nitric oxide synthase (iNOS), cyclooxygenase-2 (COX-2), interleukin (IL)-6, IL-12 and tumor necrosis factor-alpha $(\mathrm{TNF}-\alpha)$. The increased production of proinflammatory molecules attracts more inflammatory cells to the intestine, amplifying and extending the inflammatory response. Tissue damage ultimately results from the release of noxious mediators [7-9].

As one of the major regulators of inflammation, $\mathrm{NF}-\kappa \mathrm{B}$ plays a pivotal role in the activation of macrophages. In the inactive state, $\mathrm{NF}-\kappa \mathrm{B}$ associates with I $\kappa \mathrm{B}$ and is retained as a complex in the cytoplasm. Upon activation, I $\kappa$ B is phosphorylated by the IKK- $\alpha / \beta$ complex and then recognized by ubiquitinating enzymes for proteasomal degradation. The dissociated NF- $\kappa B$ will translocate into the nucleus and activate transcription of proinflammatory genes $[10,11]$. Emerging evidence also suggests a role for STAT3 in mediating the activation of macrophages. It has been shown that STAT3 is frequently phosphorylated in activated macrophages and is responsible for transcriptional induction of proinflammatory mediators [12]. Importantly, both NF$\kappa \mathrm{B}$ and STAT3 are implicated in the pathophysiology of IBD, as well as the development of colorectal cancer (CRC). It has been shown that NF- $\mathrm{NB}$ and STAT3 are markedly induced in the intestines of IBD patients and strongly influence the inflammatory process $[13,14]$. Sustained inflammatory responses in the intestines of IBD patients increase their risk for $\mathrm{CRC}$, proportional to the severity, extent and duration of the inflammation [15]. Therefore, suppression of activated $N F-\kappa B$ and STAT3 is a major focus of IBD treatment.

In recent years, herbal medicines have been widely used amongst IBD patients as complementary and alternative medicines [16, 17]. Herbal medicines can not only improve the condition of IBD patients, but are also efficient in suppressing activated NF- $\mathrm{KB}$ and STAT3, indicating their potential as a source for the discovery of anti-inflammatory agents and therapeutics for IBD [18-21]. Gynostemma pentaphyllum (Thunb.) Makino (Gp) has been widely used as an herbal medicine in Asian countries. Saponins $(\mathrm{GpS})$ are one of the major active components in $\mathrm{Gp}$ and to date there have been more than 100 dammarane-type GpS identified in Gp [22-24]. Previous studies have demonstrated that longterm treatment with $\mathrm{Gp}$ does not induce in vivo toxicity, and accumulating evidence has suggested the beneficial effects of $\mathrm{GpS}$ in a wide range of chronic diseases [25]. In particular, the strong reactive oxidative species (ROS) scavenging activity of $\mathrm{GpS}$ is thought to be important for its activity [26-29]. As ROS may initiate inflammation via activation of NF- $\mathrm{B}, \mathrm{GpS}$ may potentially exhibit anti- inflammatory effects through suppression of NF- $\kappa \mathrm{B}$ [30]. Previous studies have demonstrated the NF- $\kappa \mathrm{B}$-inhibitory effect of GpS in activated macrophages and our group has also shown that GpS is an effective inhibitor of STAT3 in the intestinal epithelium and polyps of CRC $A p c^{\mathrm{Min} /+}$ mice $[31,32]$. Given the importance of NF- $\kappa \mathrm{B}$ and STAT3 in the pathogenesis of IBD, we hypothesized that GpS may potentially be effective against IBD.

In this study, we aimed to investigate the antiinflammatory effect of $\mathrm{GpS}$ and to elucidate the potential mechanisms involved. Using the lipopolysaccharide (LPS)induced murine macrophage model and the dextran sulfate sodium (DSS)-induced acute colitis mouse model, we have demonstrated the potent anti-inflammatory effect of GpS. GpS could suppress the inflammatory response via inhibition of NF- $\mathrm{KB}$ and STAT3 signaling in vitro and in vivo, and could also ameliorate the manifestation of acute colitis in DSS-induced mice. Our findings present strong evidence of the anti-inflammatory effects of $\mathrm{GpS}$ and highlight its potential as a therapeutic agent for the treatment of IBD.

\section{RESULTS}

\section{GpS did not affect the cell viability of RAW264.7 macrophages and suppressed NO production and iNOS expression in LPS-induced RAW264.7 macrophages}

To examine the cytotoxicity of GpS in RAW264.7 macrophages, we treated the cells with 3.1 to $200 \mu \mathrm{g} / \mathrm{ml}$ GpS for 24 hrs and observed its effect on cell viability. Our results showed that there was no significant difference in the viability of cells treated with GpS compared to control, suggesting GpS did not exhibit cytotoxicity in RAW264.7 macrophages (Figure 1A). We also examined the effect of GpS in macrophages stimulated by LPS. In line with the results from unstimulated macrophages, $\mathrm{GpS}$ did not affect the cell viability of activated macrophages (Figure 1B) and therefore, doses of 100, 150 and $200 \mu \mathrm{g} / \mathrm{ml}$ were selected for downstream experiments. Next, we investigated the effect of GpS on NO production in LPS-induced macrophages. LPS-induced NO production in macrophages was significantly decreased by treatment with $\mathrm{GpS}$, in a dose-dependent manner (Figure 1C). We further examined the effect of $\mathrm{GpS}$ on the expression of iNOS, the upstream regulator for the production of NO. As shown in Figure 1D, GpS significantly suppressed the protein expression of iNOS. Notably, when compared with vehicle control, $200 \mu \mathrm{g} / \mathrm{ml} \mathrm{GpS} \mathrm{significantly} \mathrm{suppressed}$ the LPS-induced expression of iNOS by about $70 \%$. These results suggested that in LPS-induced macrophages, GpS could inhibit NO production and iNOS expression, without affecting cell viability. 


\section{GpS suppressed NF-кB signaling in LPS-induced} RAW264.7 macrophages

Upon stimulation by inflammatory signals, NF$\kappa \mathrm{B}$ signaling is activated, leading to translocation of $\mathrm{NF}-\mathrm{\kappa B} / \mathrm{p} 65$ into the nucleus of the cell and the consequent expression of multiple inflammatory and innate immune genes $[10,11]$. Therefore, we first investigated the effect of $\mathrm{GpS}$ on the nuclear translocation of NF- $\mathrm{kB} / \mathrm{p} 65$ in LPSinduced RAW264.7 macrophages. As shown in Figure 2, when compared with vehicle control, GpS treatment suppressed translocation of NF- $\mathrm{kB} / \mathrm{p} 65$ into the nucleus of LPS-induced macrophages. Further, we examined the effect of $\mathrm{GpS}$ on the expression of phosphorylated $\mathrm{NF}-\kappa \mathrm{B}$ and its upstream regulators, I $\mathrm{\kappa B}-\alpha$ and IKK- $\alpha / \beta$ by Western blotting. In comparison with vehicle control, $200 \mu \mathrm{g} / \mathrm{ml} \mathrm{GpS}$ significantly downregulated the expression

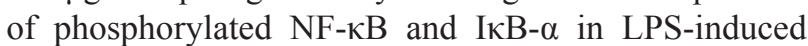
macrophages in a time dependent manner (Figure 3A).
We then studied the dose dependent effect of GpS on LPS-induced macrophages. Our results showed that GpS treatment significantly and dose dependently suppressed

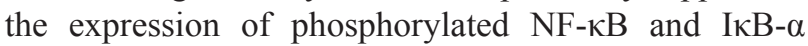
(Figure 3B). Taken together, these results suggested that GpS could suppress the activation of NF- $\mathrm{kB}$ signaling in LPS-induced macrophages, indicating its potential antiinflammatory activity.

\section{GpS suppressed STAT3 signaling in LPS-induced RAW264.7 macrophages}

Recently, STAT3 signaling has been shown to be a major contributor to the induction and maintenance of inflammation [12]. Therefore, we sought to examine if GpS could also mediate STAT3 signaling in LPS-induced macrophages. As shown in Figure 3, in LPS-induced macrophages, when compared with the vehicle control, GpS treatment significantly suppressed the expression of
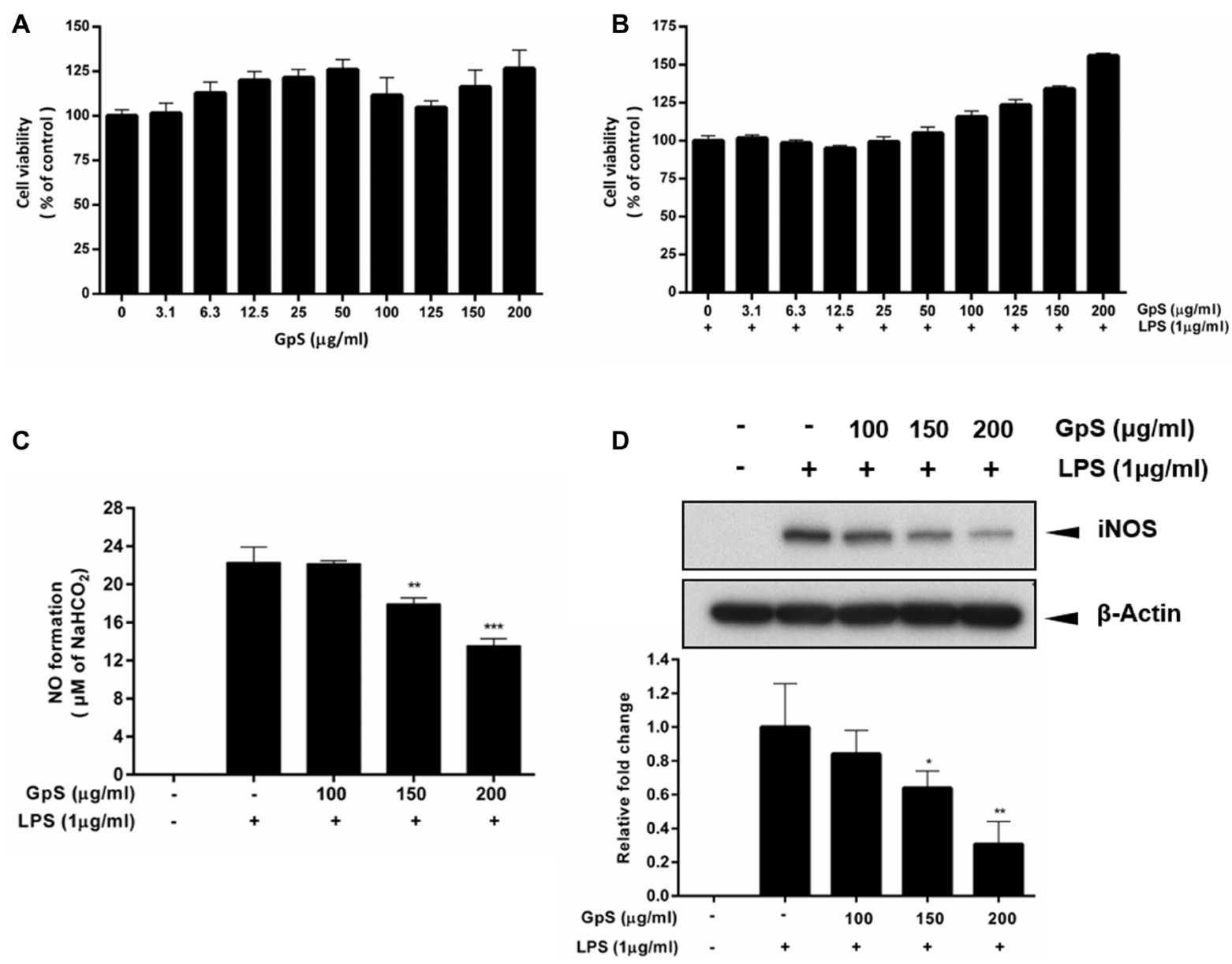

Figure 1: GpS inhibits LPS-induced NO production and iNOS expression without affecting the cell viability of RAW 264.7 macrophages. Cells were treated with GpS at concentrations ranging from 3.1 to $200 \mu \mathrm{g} / \mathrm{ml}$ in the (A) absence or (B) presence of LPS $(1 \mu \mathrm{g} / \mathrm{ml})$ for $24 \mathrm{hrs}$. Cell viability was determined by MTT assay. Cells were pre-treated for $1 \mathrm{hr}$ with indicated the concentrations of $\mathrm{GpS}$ and further incubated for $24 \mathrm{hrs}$ with or without LPS $(1 \mu \mathrm{g} / \mathrm{ml})$ before assement of $(\mathbf{C})$ NO production and (D) iNOS protein expression by Griess assay and Western blotting respectively. Representative immunoblot results and their quantifications are shown. $\beta$-actin was used as an internal loading control. Data are expressed as means $\pm \mathrm{SD}$ of three independent experiments. ${ }^{*} P<0.05,{ }^{* *} P<0.01,{ }^{* * *} P<0.001$ compared to LPS-induced control. 
STAT3 in a time and dose dependent manner, suggesting that GpS could also inhibit STAT3 signaling during inflammation.

\section{GpS ameliorated the severity of DSS-induced acute colitis in mice}

The DSS-induced acute colitis mouse model is a well-established animal model for the study of IBD [33]. Using this model, we examined the antiinflammatory and therapeutic effects of GpS on IBD in vivo. As four weeks of treatment with 500 or $750 \mathrm{mg} /$ $\mathrm{kg} \mathrm{GpS}$ in $A p c^{\mathrm{Min} /+}$ mice did not induce significant adverse effects in our previous study [32], we selected $500 \mathrm{mg}$ / $\mathrm{kg}$ (low dose; GpS-L) and $800 \mathrm{mg} / \mathrm{kg}$ (high dose; GpS-H) doses of $\mathrm{GpS}$ for this study. Administration of $2 \% \mathrm{DSS}$ in drinking water for 7 consecutive days successfully induced weight loss, and decreased food and water intake in mice treated with vehicle (Figure 4A-4C). In comparison, treatment with GpS-L or GpS-H during DSS administration rescued weight loss and improved food and water intake, as well as decreased DSS-induced disease activity index (DAI) values (Figure 4A-4D). Moreover, $\mathrm{GpS}$ treatment also ameliorated colon shortening in mice, from a $25 \%$ reduction to $21 \%$ and $15 \%$ with GpS-L or GpS-H treatment respectively (Figure 4E). Histological analysis also indicated the beneficial effects of $\mathrm{GpS}$ treatment. As shown in Figure 4F, colon sections from DSS-induced mice under vehicle treatment exhibited the inflammatory cell infiltration and destruction of epithelial cell architecture typical of acute colitis, whereas treatment with GpS-L or GpS-H ameliorated the damage induced by DSS. In addition, colon sections from mice receiving GpS-H treatment showed minimal epithelial damage
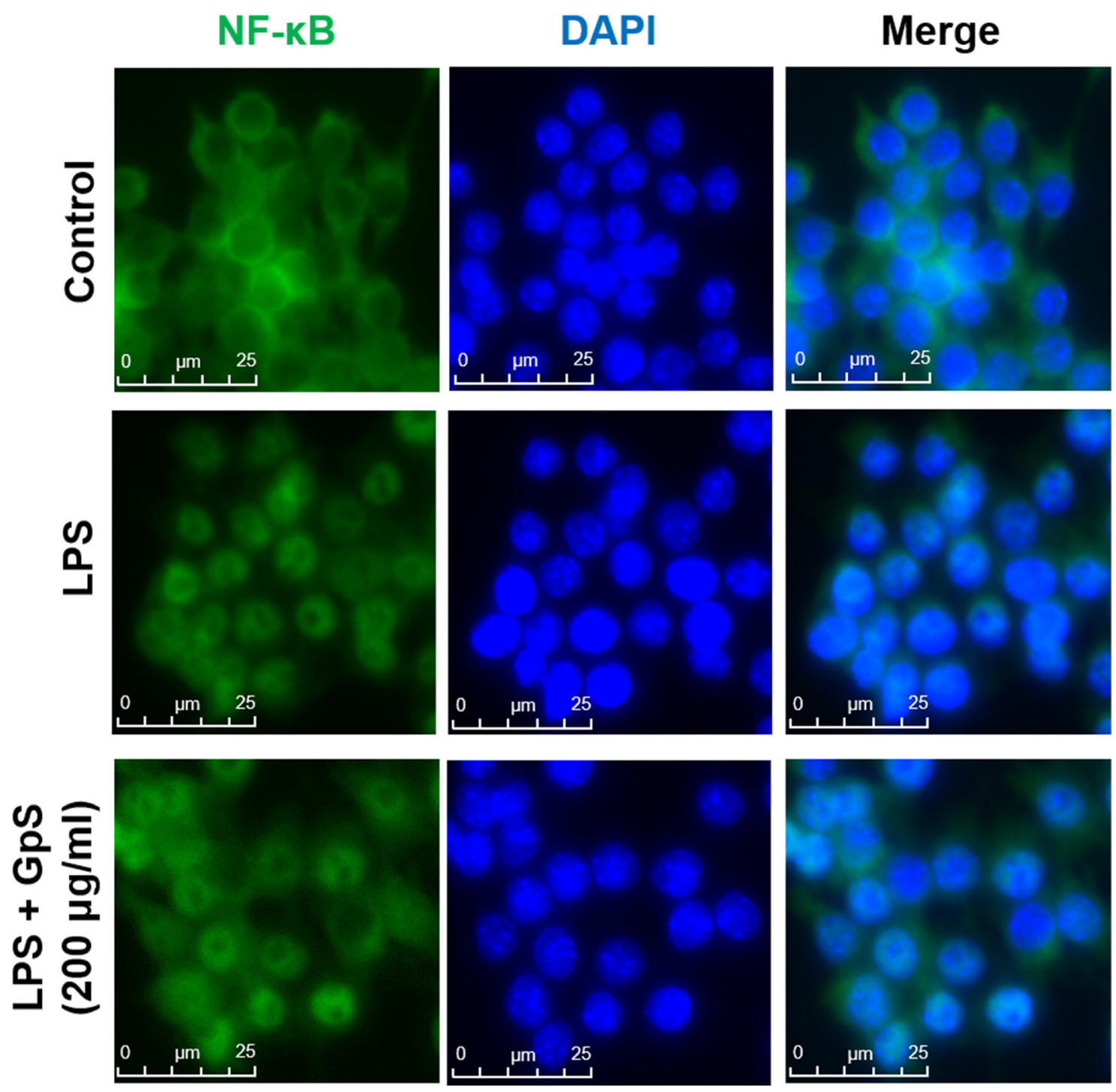

Figure 2: GpS inhibits nuclear translocation of NF-кB/p65 in LPS-induced RAW 264.7 macrophages. Cells were pretreated with or without GpS $(200 \mu \mathrm{g} / \mathrm{ml})$ for $12 \mathrm{hrs}$ and then exposed to LPS $(1 \mu \mathrm{g} / \mathrm{ml})$ for $1 \mathrm{hr}$. Cells were then fixed, permeabilized and processed for immunofluorescent staining of $\mathrm{NF}-\kappa \mathrm{B} / \mathrm{p} 65$. Nuclei were stained with DAPI. 
or crypt loss when compared with vehicle control, and strikingly, these results were comparable to the uninduced control group.

\section{GpS suppressed cytokine production in the colons of DSS-induced acute colitis mice}

A dysregulated immune system is known to be one of the major contributors to the development of IBD, leading to a proinflammatory cytokine profile in IBD patients $[3,4,34]$. To examine the effect of $\mathrm{GpS}$ on cytokine profiles in mice, we used organ primary culture, which has previously been used to study cytokine production in intestinal disorders $[33,35]$. Colon sections obtained from mice after sacrifice were cultured, and the conditioned media pooled and analyzed using a Bio-Plex Pro Mouse Cytokine23-Plex Panel kit. As shown in Figure 5, production of IL-6, IL-12 (p70), IFN- $\gamma$ and TNF- $\alpha$ were significantly increased in colons of DSS-induced mice when compared with uninduced control. In comparison with vehicle treatment, GpS-L or GpS-H significantly downregulated production of these proinflammatory cytokines in DSS-induced mice (Figure 5). As IL-6 and TNF- $\alpha$ are two of the most dysregulated cytokines in IBD patients [36], we further validated their levels in the conditioned media of individual mice colons. In agreement with the results from the Bioplex cytokine assay, GpS-L or GpS-H significantly downregulated the production of IL-6 and TNF- $\alpha$ in mice colons when compared to vehicle (Figure 6).

\section{GpS suppressed NF- $\mathrm{NB}$ and STAT3 signaling in colons of DSS-induced acute colitis mice}

Based on the above results, we further examined the effects of GpS on iNOS, NF- $\mathrm{BB}$ and STAT3 signaling in
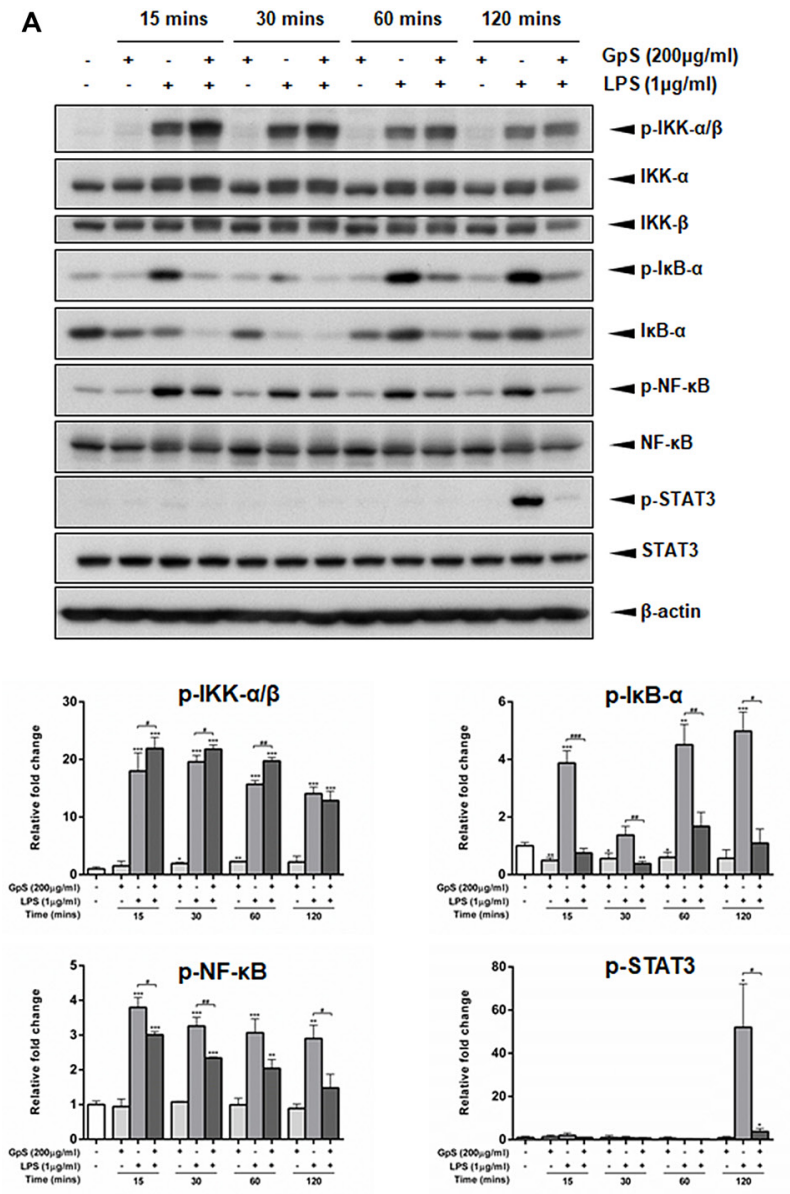

B

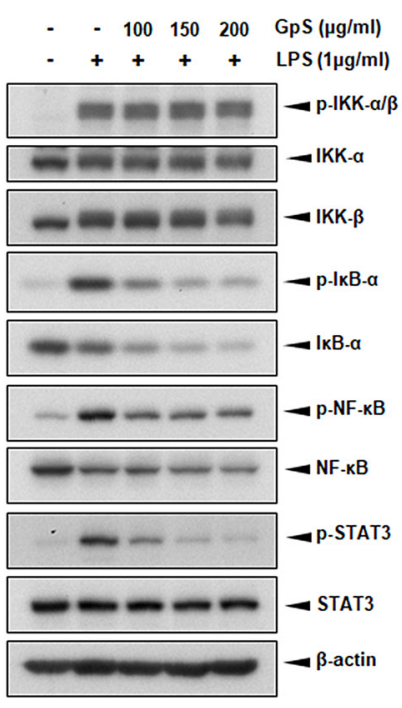

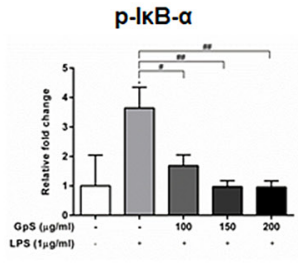
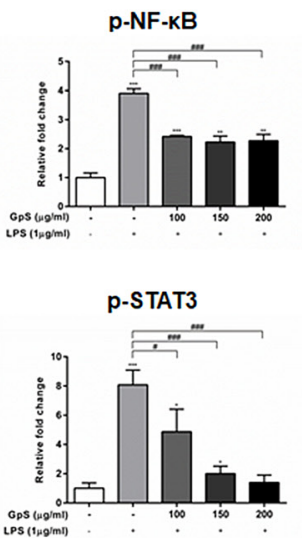

Figure 3: GpS inhibits IкB- $\alpha$, NF-кB and STAT3 phosphorylation in LPS-induced RAW 264.7 macrophages. (A) Cells were pre-treated with or without $200 \mu \mathrm{g} / \mathrm{ml} \mathrm{GpS}$ for $1 \mathrm{hr}$ and then exposed to LPS $(1 \mu \mathrm{g} / \mathrm{ml})$ for the indicated times. (B) Cells were pretreated with or without different concentrations of GpS for $1 \mathrm{hr}$ and then exposed to LPS $(1 \mu \mathrm{g} / \mathrm{ml})$ for 2 hrs. The protein levels of phospho-

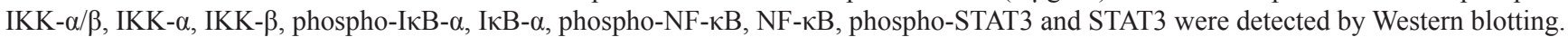
$\beta$-actin was used as an internal loading control. Three independent experiments were performed and representative immunoblots and quantifications are shown. Data are expressed as means $\pm \mathrm{SD} ;{ }^{*} P<0.05,{ }^{* *} P<0.01,{ }^{* * *} P<0.001$ compared to untreated control; ${ }^{\#} P<0.05$, ${ }^{\#} P<0.01,{ }^{\#} P<0.001$ compared to LPS-induced control. 
A

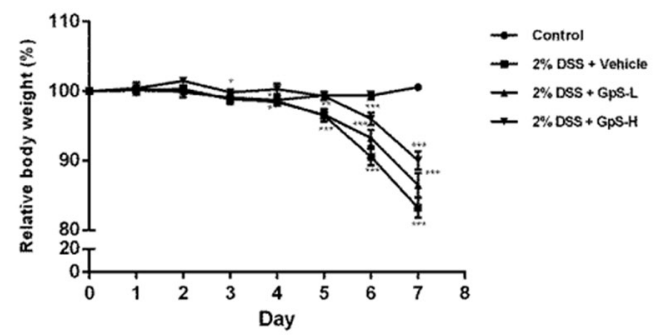

B

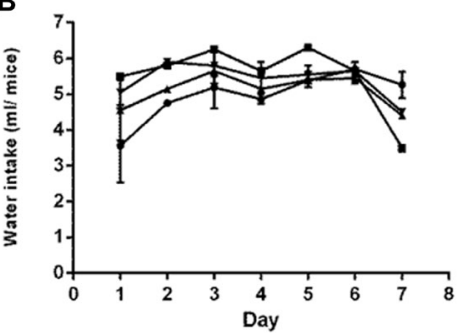

C

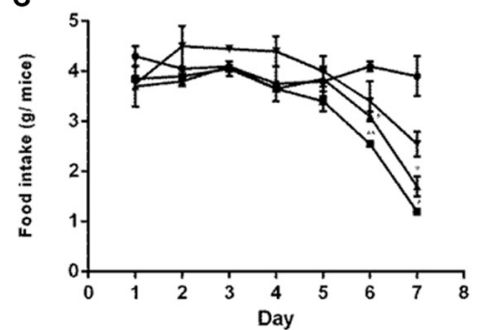

D
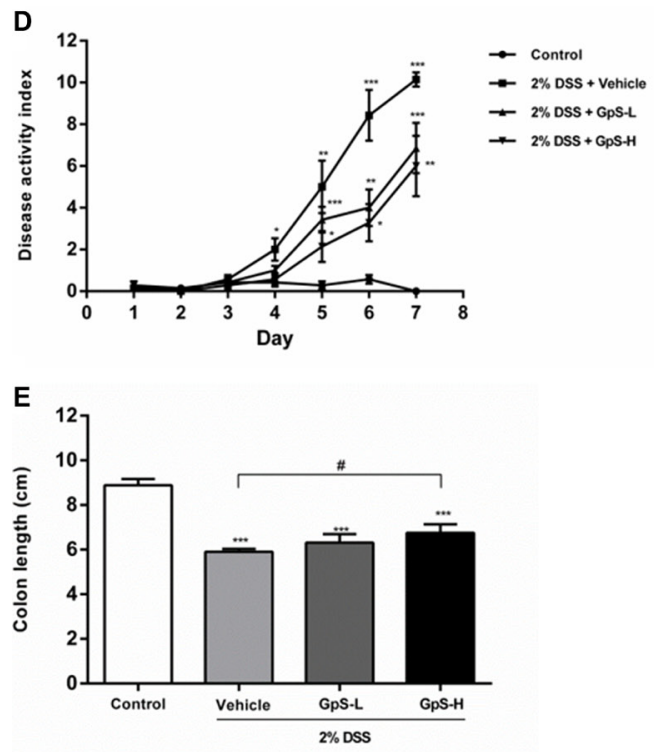

F

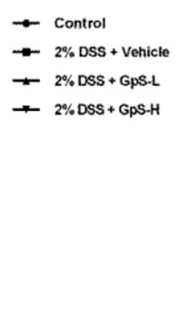

$\rightarrow$ control

- $2 \%$ Dss + Venicle

$+2 \%$ DSS + GpSSL

$2 \%$ DSS + GPS.H

ณ
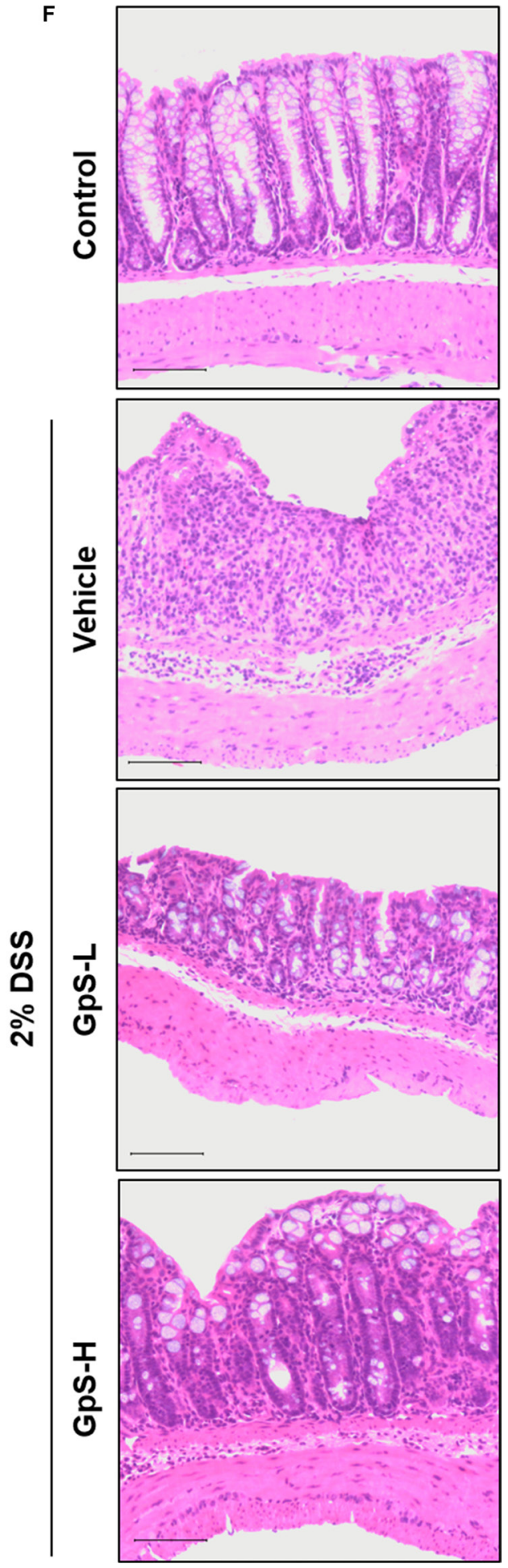

Figure 4: GpS ameliorates the severity of DSS-induced acute colitis in mice. Acute colitis was induced by supplying mice with $2 \%$ DSS in their drinking water for seven consecutive days. Mice were orally administered with vehicle $(0.5 \% \mathrm{CMC})$, GpS-L $(500 \mathrm{mg} / \mathrm{kg} \mathrm{GpS}$ in $0.5 \% \mathrm{CMC})$ or $\mathrm{GpS}-\mathrm{H}(800 \mathrm{mg} / \mathrm{kg} \mathrm{GpS}$ in $0.5 \% \mathrm{CMC})$ alongside DSS induction. Control mice received filtered water and $0.5 \%$ CMC. (A) Body weights were measured daily ( $n=7$ per group) and are presented as the group mean percentage change from initial \pm SEM. Daily changes in (B) water consumption, (C) food intake, (D) disease activity index were measured. At the experimental endpoint, (E) colon lengths were measured. (F) Histological changes were visualized by hematoxylin and eosin staining of paraffin embedded colon sections and assessed under light microscopy. Control group shows normal colon histology of mice. Vehicle group shows typical acute colitis features, including destruction of epithelial integrity and crypts and inflammatory cell infiltration in the colons. GpS treatment group retains the epithelial cell architecture and reduces the morphological alteration resulting from DSS treatment. Data are expressed as means $\pm \mathrm{SEM} ;{ }^{*} P<0.05,{ }^{* *} P<0.01$, ${ }^{* * *} P<0.001$ compared to uninduced control; ${ }^{\#} P<0.05,{ }^{\# \#} P<0.01,{ }^{\# \#} P<0.001$ compared to $2 \%$ DSS-induced vehicle group. 
the colons of DSS-induced mice. As shown in Figure 7, $\mathrm{GpS}$ treatment dose-dependently downregulated the DSS-induced expression of iNOS when compared with vehicle. In addition, $\mathrm{GpS}$ also mediated the expression of phosphorylated IKK $-\alpha / \beta$, I $\kappa$ B $-\alpha$, NF- $\kappa$ B and STAT3, echoing the results from our in vitro experiments. To confirm these results, we examined the expression of these four proteins in mice colons using immunohistochemical (IHC) analysis. In accordance with the Western blot results, GpS-L or GpS-H treatment reduced the DSSinduced expression of phosphorylated IKK- $\alpha / \beta$, I $\kappa \mathrm{B}-\alpha$, $\mathrm{NF}-\kappa \mathrm{B}$ in mice colons (Figure 8).

\section{DISCUSSION}

As a chronic, relapsing gastrointestinal inflammatory disorder, the treatment goals for IBD are to induce and maintain remission of symptoms and mucosal inflammation, ultimately improving the quality of life of the IBD patient [37]. At present, 5-ASA and corticosteroids remain as the major treatment options for IBD. However, side effects and adverse events from these treatments can hinder their therapeutic selection [38, 39]. In the past several years, a host of new treatment options have been developed or are currently in clinical trials, including immunotherapies such as anti-TNF or anti-IL-12/23 antibodies. Although these agents have been shown to be quite effective and safe, they do not treat the underlying cause of the disease and are only effective in a subset of the population $[40,41]$. As the incidence and prevalence of IBD continues to rise worldwide [1, 2], demand for potent, non-toxic and effective therapeutics for treatment of the disease is increasing. Gynostemma pentaphyllum has been widely used as a herbal medicine in Asian countries, and its saponins (GpS) have been shown to possess potent anti-inflammatory effects. Therefore, we have performed a systematic study to investigate the anti-inflammatory effect of $\mathrm{GpS}$ and its underlying mechanisms in IBD.

It has been shown that overexpression of iNOS and the subsequent production of NO are associated with the initiation and maintenance of IBD. In the active state of IBD, NO concentration and iNOS protein expression were increased in colons of patients when compared with control, suggesting a potential role of NO and iNOS in
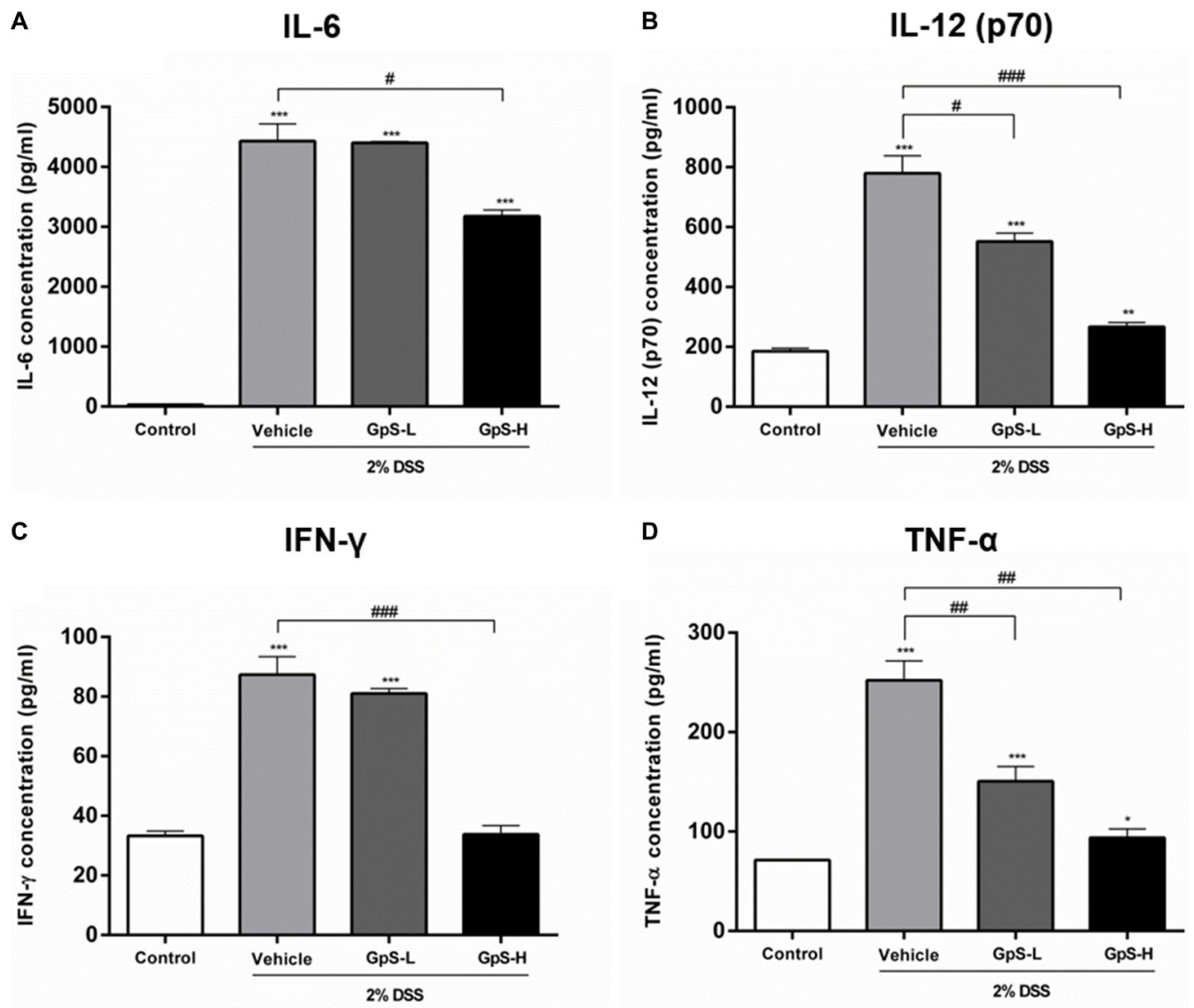

Figure 5: GpS suppresses proinflammatory cytokine production of colons from mice with DSS-induced acute colitis. Colon sections from mice were removed at the end of experiment, cultured and the conditioned media pooled for Bioplex mouse cytokine assay. Measurement of (A) IL-6, (B) IL-12 (p70), (C) IFN- $\gamma$ and (D) TNF- $\alpha$ in colon culture media. Data are expressed as means \pm SEM; ${ }^{*} P<0.05,{ }^{* *} P<0.01,{ }^{* * *} P<0.001$ compared to uninduced control; ${ }^{\#} P<0.05,{ }^{\#} P<0.01,{ }^{\# \#} P<0.001$ compared to $2 \%$ DSS-induced vehicle group. 
mediating the pathogenesis of IBD [7, 8, 42]. As in previous studies [31], our current study identified a strong suppressive effect of $\mathrm{GpS}$ on iNOS protein expression and NO production in LPS-induced macrophages, indicating the potential efficacy of GpS in IBD.

$N F-\kappa B$ has been shown to mediate the activation of iNOS as an upstream regulator [43]. In the presence of stimuli such as LPS or bacteria, the IKK- $\alpha / \beta$ complex is phosphorylated, resulting in phosphorylation of NF$\kappa \mathrm{B}$-bound I $\mathrm{I} \mathrm{B}$. Consequently, phosphorylated $\mathrm{I} \kappa \mathrm{B}$ is targeted for proteosomal degradation and $\mathrm{NF}-\kappa \mathrm{B}$ is released. Nuclear translocation of $\mathrm{NF}-\kappa \mathrm{B}$ then increases the transcription of genes encoding proinflammatory molecules including chemokines, cytokines and proinflammatory enzymes, forming an amplifying feedforward loop $[11,13,44]$. It has been shown that NF- $\mathrm{BB}$ is markedly induced in the intestines of IBD patients and its expression level strongly influences progression of the disease $[10,11]$, therefore suppression of $N F-\kappa B$ activation is a major focus of IBD treatment. In addition, emerging evidence has suggested a role for STAT3 in IBD. It has been shown that STAT3 signaling is constitutively activated in IBD patients and that activation of STAT3 is responsible for triggering the innate immune response, leading to the production of proinflammatory mediators [12]. Thus, we focused on the effect of GpS on the $\mathrm{NF}-\kappa \mathrm{B}$ and STAT3 signaling pathways. Our results clearly showed that GpS treatment could suppress the nuclear translocation of $\mathrm{NF}-\kappa \mathrm{B} / \mathrm{p} 65$ in LPS-induced macrophages. In addition, when compared with vehicle control, GpS significantly inhibited the protein expression of phospho-NF- $\mathrm{B}$ and phospho-STAT3 in a time and dose dependent manner in the macrophages, suggesting the anti-inflammatory potential of $\mathrm{GpS}$.

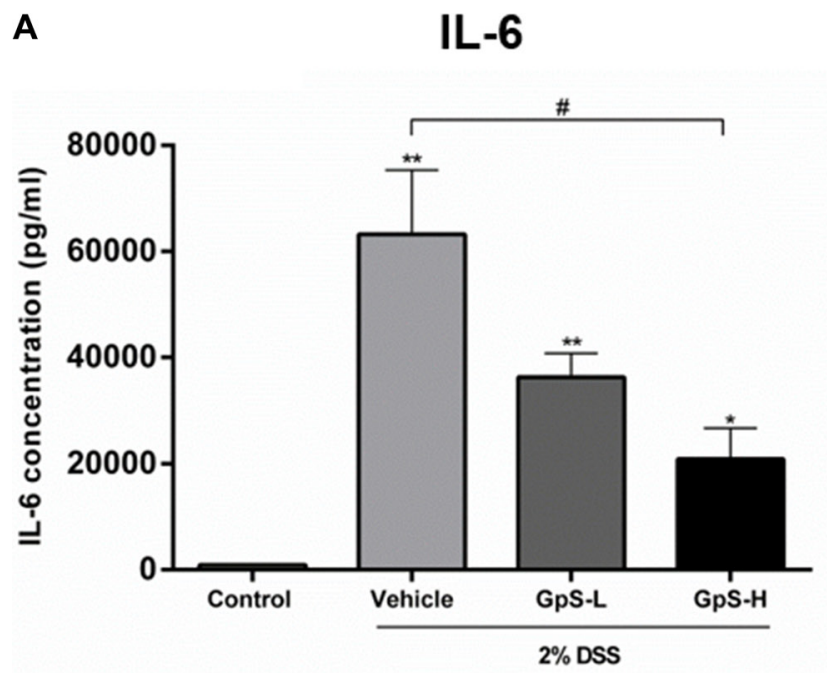

We furthered our study in a chemically-induced colitis mouse model to examine the in vivo antiinflammatory effect of GpS. The DSS-induced acute colitis mouse model is a well-established animal model for the study of IBD which mimics the disease manifestation and histopathological characteristics of IBD patients, making it advantageous to other animal models for in vivo studies [45]. Mice under vehicle treatment exhibited typical acute colitis manifestations, including weight loss, shortening of colon length and increased DAI. Microscopic evaluation of mice colons showed that GpS treatment improved the DSS-induced inflammatory cell infiltration and destruction of epithelial cell architecture.

As proinflammatory cytokines are responsible for mucosal injury and consequential tissue damage in IBD patients via the induction of proinflammatory signaling pathways [36, 46], suppression of proinflammatory cytokine production and signaling pathways would be beneficial for treatment of disease. Using organ primary culture and cytokine assays, we examined the effect of $\mathrm{GpS}$ on the cytokine production of the colons of DSS-induced mice. Our results demonstrated that GpS treatment attenuated the production of proinflammatory cytokines, which may be beneficial for inhibiting the progression of IBD [47]. More importantly, the production of TNF- $\alpha$ and IL- 6 were significantly suppressed by GpS treatment. It has been shown that in addition to being target genes of activated NF- $\mathrm{NB}$ and STAT3 signaling, TNF- $\alpha$ and IL-6 could also trigger the activation of $\mathrm{NF}-\kappa \mathrm{B}$ and STAT3 signaling [12, 48, 49]. As colon biopsies and sera from IBD patients have increased concentrations of TNF- $\alpha$ and IL-6, the suppressive effect of GpS on TNF- $\alpha$ and IL- 6 production in the colons of colitis mice may also indicate the potential inhibitory

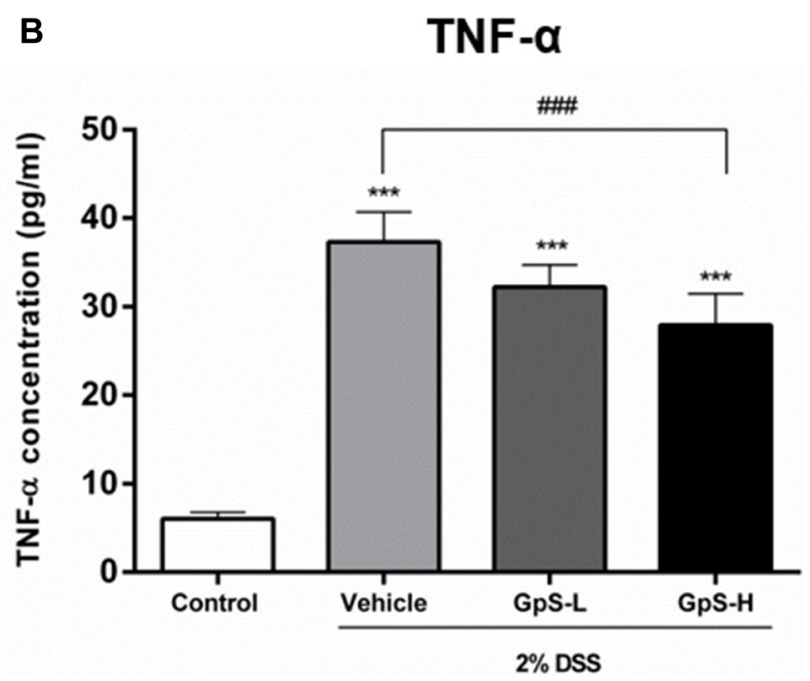

Figure 6: Validation of the suppressive effect of GpS on cytokine production in mice colons with DSS-induced acute colitis. Concentrations of (A) IL-6 and (B) TNF- $\alpha$ in the colon cultures of individual mice from each group $(n=3)$ were measured by ELISA. Data are expressed as means $\pm \mathrm{SEM} ;{ }^{*} P<0.05,{ }^{* *} P<0.01,{ }^{* * *} P<0.001$ compared to uninduced control; ${ }^{\#} P<0.05,{ }^{\# \#} P<0.01$, ${ }^{\# \# \# P} P$. 001 compared to $2 \%$ DSS-induced vehicle group. 


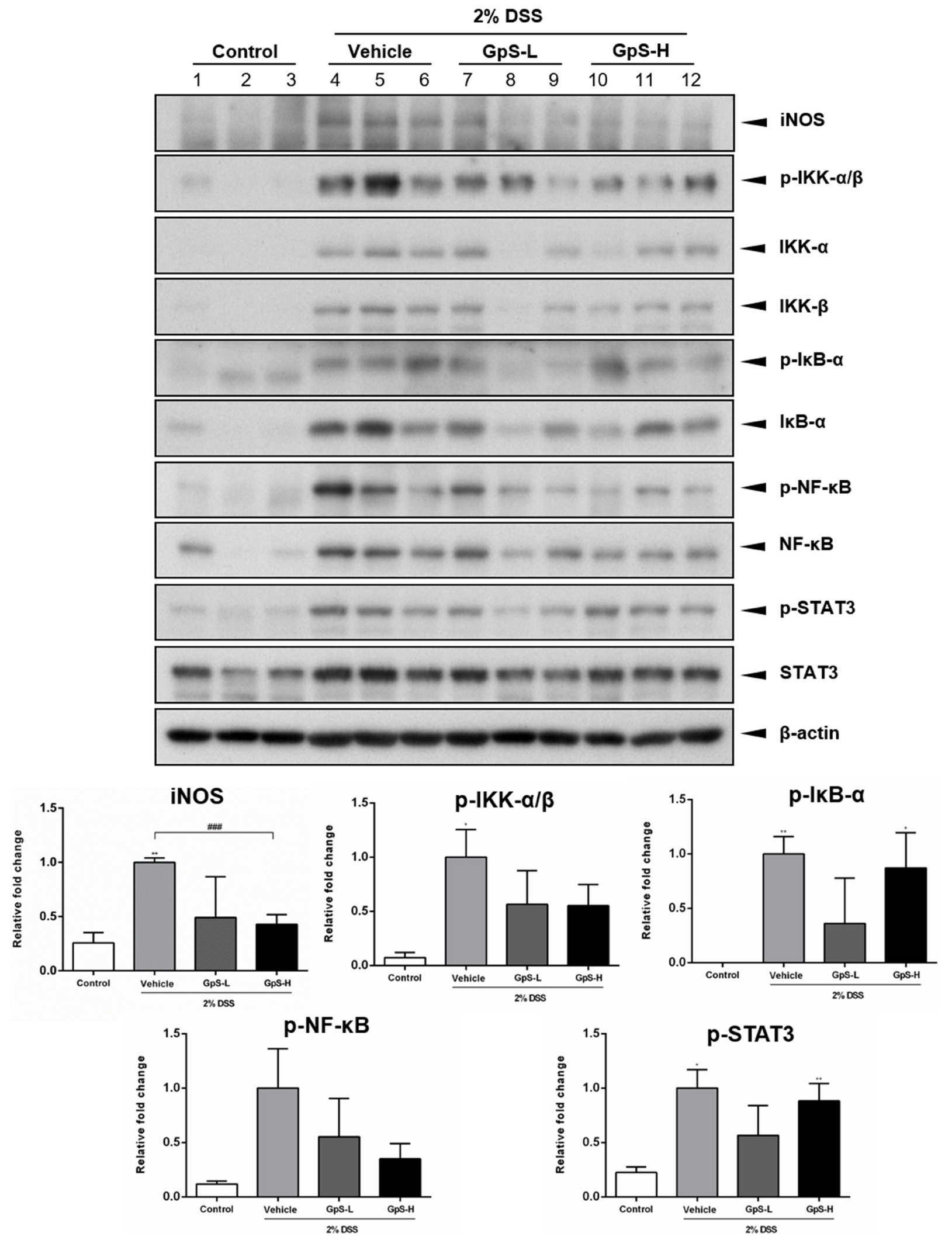

Figure 7: GpS suppresses iNOS, NF-кB and STAT3 signaling in colonic tissue of DSS-induced mice. Colon tissues were

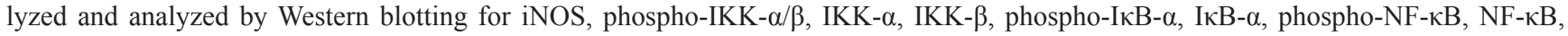
phospho-STAT3 and STAT3. $\beta$-actin was used as an internal loading control. Representative immunoblots and their quantifications are shown. Data are expressed as means $\pm \mathrm{SEM} ;{ }^{*} P<0.05,{ }^{* *} P<0.01,{ }^{* * *} P<0.001$ compared to uninduced control; ${ }^{\#} P<0.05,{ }^{\#} P<0.01$, ${ }^{\# \prime \prime \prime} P<0.001$ compared to $2 \%$ DSS-induced vehicle group. 
effect of GpS on NF- $\kappa \mathrm{B}$ and STAT3 signaling. As expected, $\mathrm{GpS}$ treatment suppressed the proteins involved in NF- $\mathrm{kB}$ and STAT3 signaling. More importantly, we found that $\mathrm{GpS}$ potently downregulated phospho-NF- $\mathrm{\kappa B}$ in both cell and animal experiments, suggesting that $\mathrm{GpS}$ may act as an inhibitor of NF- $\mathrm{\kappa B}$ in the treatment of IBD, suppressing the production of proinflammtory cytokines and consequential tissue damage in patients.

In conclusion, we have provided evidence of the anti-inflammatory effects of $\mathrm{GpS}$ in vitro and in vivo. GpS could inhibit the production of proinflammatory cytokines and suppress activation of the proinflammatory NF- $\mathrm{KB}$ and STAT3 signaling pathways in colons of DSS-induced acute colitis mice, while improving their condition (Figure 9). Our data not only provides evidence of the anti-inflammatory effects of $\mathrm{GpS}$, but also highlights the potential of $\mathrm{GpS}$ as a therapeutic agent for the treatment of IBD.

\section{MATERIALS AND METHODS}

\section{Preparation of GpS}

GpS were purchased from Hauduo Natural Products (Guangzhou, China). Authentication and chemical profiling of each batch was conducted in our laboratory as previously reported [32].

\section{Cell culture and in vitro stimulation of macrophages}

RAW264.7 murine macrophages were maintained as previously described [50]. For the cell viability assay, $1 \times 10^{4}$ RAW264.7 macrophages were plated in a 96-well plate for $24 \mathrm{hrs}$ and then treated with $\mathrm{GpS}$ at concentrations ranging from $3.1-200 \mu \mathrm{g} / \mathrm{ml}$ for $24 \mathrm{hrs}$ or treated with

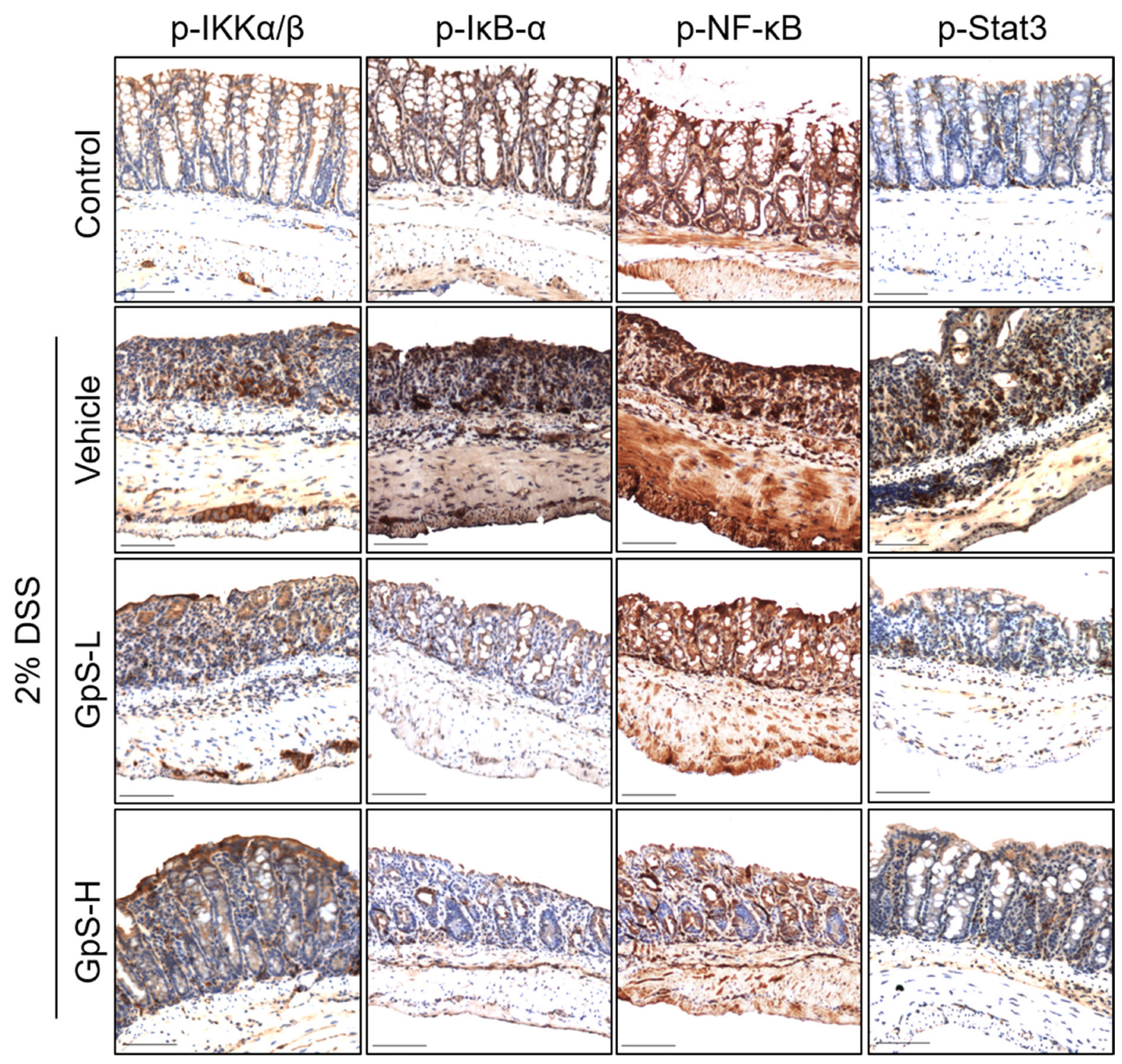

Figure 8: GpS inhibits the activation of NF-KB and STAT3 signaling in DSS-induced mice. Paraffin embedded colon

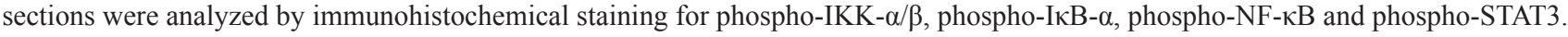


GpS (3.1-200 $\mu \mathrm{g} / \mathrm{ml})$ for $1 \mathrm{hr}$ before co-treatment with $1 \mu \mathrm{g} / \mathrm{ml}$ LPS (Sigma-Aldrich, St. Louis, MO, USA) for 24 hrs. Cell viability was then measured using MTT (Sigma-Aldrich). For NO and cytokine production measurement and Western blotting, $1 \times 10^{6}$ RAW264.7 macrophages were treated with $0,100,150$, or $200 \mu \mathrm{g} / \mathrm{ml}$ GpS $1 \mathrm{hr}$ before co-treatment with LPS $(1 \mu \mathrm{g} / \mathrm{ml})$ and $\mathrm{GpS}$ for $24 \mathrm{hrs}$ or as indicated. Cells without treatment served as controls. After the treatment period, culture medium was collected and centrifuged to remove debris. Media was then aliquoted and stored at $-80^{\circ} \mathrm{C}$ until use. Cells were washed with PBS and cell pellets collected were stored at $-80^{\circ} \mathrm{C}$ until use. For immunofluorescence staining of $\mathrm{NF}-\kappa \mathrm{B} / \mathrm{p} 65$, procedures were carried out following those by Qian et al. [51], with slight modifications. Briefly, $1 \times 10^{6}$ RAW264.7 macrophages were seeded in a $\mu$-Slide 8 well chambered coverslip (ibidi, Martinsried, Germany) for $24 \mathrm{hrs}$. Cells were pretreated with or without GpS $(200 \mu \mathrm{g} / \mathrm{ml})$ for $12 \mathrm{hrs}$ and then stimulated with LPS $(1 \mu \mathrm{g} / \mathrm{ml}$ ) for $1 \mathrm{hr}$. Cells were then fixed, permeablized and stained for NF- $\mathrm{KB}$. Nuclei were stained with $300 \mathrm{nM}$ DAPI solution (Molecular Probes, Life Technologies) and then mounted with fluorescent mounting medium (Dako, Agilent, Santa Clara, CA, USA). Cells were examined by fluorescence microscopy using a Leica DMI 3000B inverted microscope (Leica Microsystems, Wetzlar, Germany).

\section{Measurement of NO production}

NO levels in conditioned media from RAW264.7 macrophages were determined using the Griess Reagent System according to the manufacturer's instructions (Promega, Madison, WI, USA).

\section{Animals and DSS-induced acute colitis}

Wild-type C57BL/6J mice were bred and acute colitis was induced as described previously [50]. Animals were randomly assigned into 3 groups ( $n=7$ per group) and were induced by providing $2 \% \mathrm{w} / \mathrm{v}$ DSS (reagent grade; 36 000-50 000 Da; MP Biomedicals, Solon, OH, USA) in drinking water for seven consecutive days. Mice were treated daily by gavage as follows: (a) vehicle: $0.5 \%$

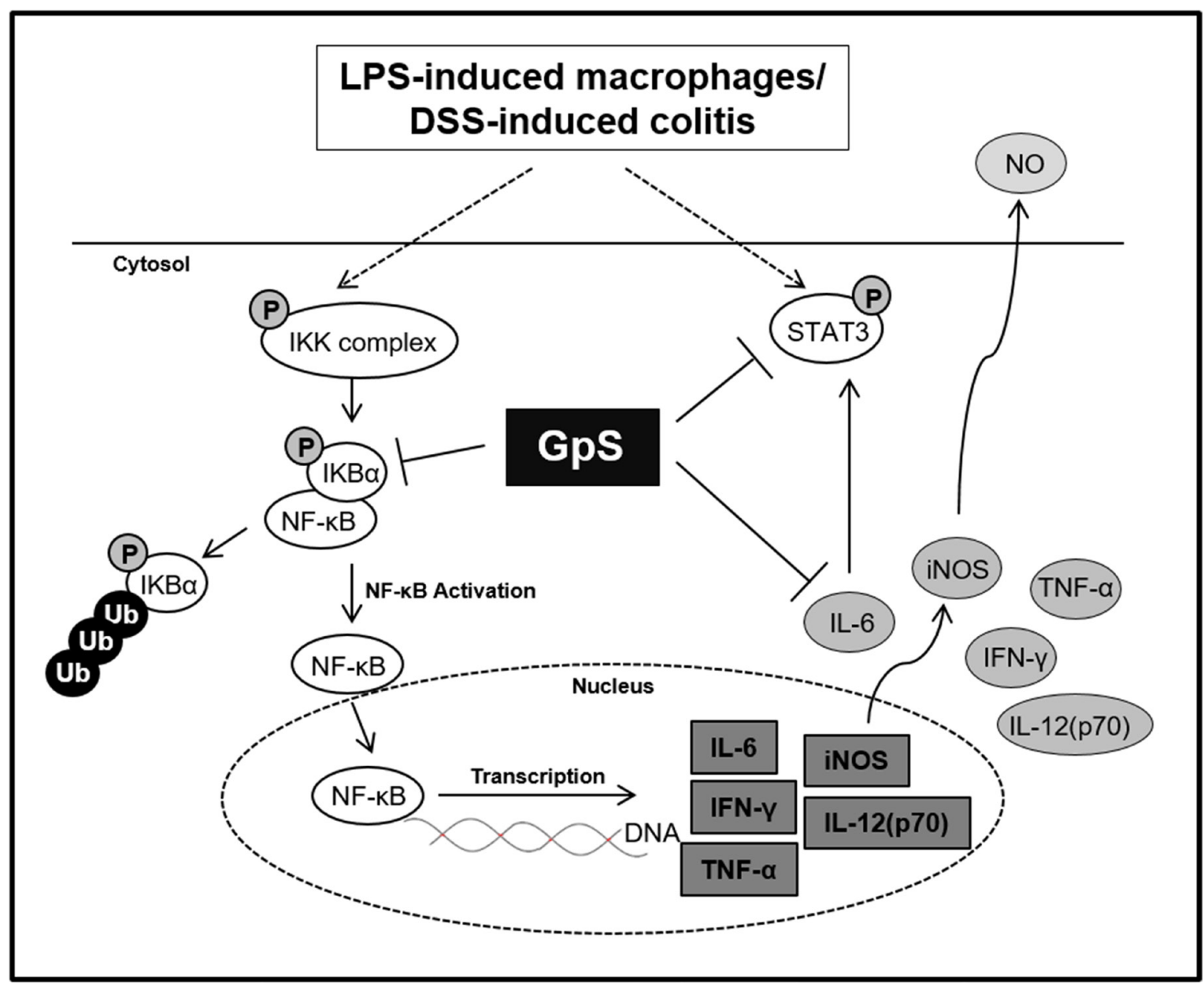

Figure 9: A schematic diagram proposing the potential inhibitory role of GpS in inflammatory signaling pathways. GpS potentially attenuated inflammatory responses through inhibiting the activity of NF- $\mathrm{kB}$ and STAT3 in LPS-induced RAW264.7 macrophages and DSS-induced acute colitis mice. 
Table 1: Disease activity index (DAI') scoring system parameters

\begin{tabular}{llll}
\hline Score & Weight loss & Stool consistency & Visible blood in feces \\
\hline 0 & None & Normal & None \\
1 & $1-5 \%$ & & \\
2 & $6-10 \%$ & Loose & Slight bleeding \\
3 & $11-20 \%$ & & \\
4 & $<20 \%$ & Diarrhea & Gross bleeding \\
\hline
\end{tabular}

"DAI value is calculated as the sum of scores of weight loss, stool consistency and visible blood in feces.

CMC; (b) low dose GpS (GpS-L): $500 \mathrm{mg} / \mathrm{kg} \mathrm{GpS}$ in $0.5 \%$ $\mathrm{CMC}$ and (c) high dose $\mathrm{GpS}(\mathrm{GpS}-\mathrm{H}): 800 \mathrm{mg} / \mathrm{kg} \mathrm{GpS}$ in $0.5 \%$ CMC. During the treatment period, mice continued to receive $2 \%$ DSS in their drinking water. A control group $(n=7)$ received drinking water (without DSS) with vehicle treatment $(0.5 \% \mathrm{CMC})$. All animal experiments were approved by the Animal Subjects Ethics Sub-Committee (ASESC) of The Hong Kong Polytechnic University and conducted in accordance with the Institutional Guidelines and Animal Ordinance of the Department of Health, Hong Kong S.A.R..

\section{Assessment of colitis}

Body weight, food and water consumption were measured daily throughout the experiment. Stool consistency and visible blood in feces were also examined. DAI was determined according to criteria reported by Marin et al. [52], parameters of which are outlined in Table 1. At the time of sacrifice, intestines were removed and colon lengths were measured. Colons were then opened longitudinally and washed with saline. Colon sections were either fixed in formalin solution for histopathological assessment, cultured in medium for cytokine level assessment or snap frozen at $-80^{\circ} \mathrm{C}$ for protein isolation.

\section{Colon tissue culture}

Colon tissue culture was performed as described by Wirtz et al. [33] with slight modifications. Briefly, isolated mice colon sections approximately $1 \mathrm{~cm}$ in length were washed thoroughly with sterile PBS and cultured in RMPI 1640 culture medium supplemented with $10 \%$ FBS at $37^{\circ} \mathrm{C}$ for $24 \mathrm{hrs}$. Conditioned media was centrifuged to remove debris and the supernatant was collected. Cytokine production was assessed using Bioplex mouse cytokine assay and ELISA.

\section{Bioplex mouse cytokine assay and measurement of cytokine production}

Cytokine levels of the colon tissue cultures were measured using the Bio-Plex 200 System (Bio-Rad, Hercules, CA, USA) with the Bio-Plex Pro Mouse Cytokine23-Plex Panel kit (Bio-Rad), according to the manufacturer's instructions. Concentration of IL-6 and TNF- $\alpha$ were measured using ELISA kits (BioLegend, Cambridge, UK) according to the manufacturer's instructions.

\section{Western blot analysis}

RAW264.7 cell pellets and colon tissues were lysed in RIPA buffer $(50 \mathrm{mM}$ Tris- $\mathrm{HCl}, \mathrm{pH} 7.4,150$ $\mathrm{mM} \mathrm{NaCl}, 1 \mathrm{mM}$ EDTA, $1 \%$ Triton $\mathrm{X}-100,1 \%$ sodium deoxycholate, $0.1 \%$ SDS) and then centrifuged to remove debris. Western blotting was carried out as previously reported [50] using the following antibodies: $\beta$-actin (Santa Cruz Biotechnology, Santa Cruz, CA, USA), iNOS (BD Biosciences, CA, USA), IKK- $\alpha$, IKK- $\beta$, phospho-

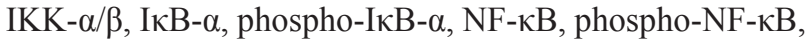
STAT3 and phospho-STAT3 (Cell Signaling Technology, Danvers, MA, USA).

\section{Immunohistochemical staining}

Expression of phospho-IKK- $\alpha / \beta$, phospho-IкB- $\alpha$, phospho-NF- $\mathrm{kB}$ and phospho-STAT3 in colon tissues were evaluated using IHC staining as previously reported [32].

\section{Statistical analysis}

Statistical analyses of cell viability, NO and cytokine production, mice body weight, food and water consumption, colon length and immunoblot densitometry were conducted using a one way analysis of variance (ANOVA). ${ }^{*} P<0.05,{ }^{* *} P<0.01$ and ${ }^{* * *} P<0.001$ were considered as significant differences. Data are presented as mean $\pm \mathrm{SD}$ (cell experiments) or mean \pm SEM (animal experiments) of three independent experiments.

\section{Abbreviations}

IBD: Inflammatory bowel disease; GpS: Gynostemma pentaphyllum saponins; UC: Ulcerative colitis; CD: Crohn's disease; iNOS: Induced nitric oxide synthase; COX-2: Cyclooxygenase-2; IL: Interleukin; TNF- $\alpha$ : Tumor necrosis factor-alpha; CRC: Colorectal cancer; ROS: Reactive oxygen species; LPS: Lipopolysaccharide; DSS: Dextran sulfate sodium (DSS); DAI: Disease activity index; 
IHC: Immunohistochemical; ANOVA: Analysis of variance.

\section{Author contributions}

WYW, MMLL and BDC performed the experiments. VWSM conducted the IHC experiments and TTCY conducted the IHC analysis. WYW, MMLL, BDC and WCZ conducted data analysis. WCST and WTW designed the experiments and wrote the manuscript.

\section{ACKNOWLEDGMENTS AND FUNDING}

This work was supported in part by the Hong Kong Research Grants Council General Research Fund (Project \#12103515) to WCST.

\section{CONFLICTS OF INTEREST}

The authors declare no conflicts of interest.

\section{REFERENCES}

1. Molodecky NA, Soon IS, Rabi DM, Ghali WA, Ferris M, Chernoff G, Benchimol EI, Panaccione R, Ghosh S, Barkema HW, Kaplan GG. Increasing incidence and prevalence of the inflammatory bowel diseases with time, based on systematic review. Gastroenterology. 2012; 142:46-54 e42; quiz e30.

2. Ananthakrishnan AN. Epidemiology and risk factors for IBD. Nat Rev Gastroenterol Hepatol. 2015; 12:205-17.

3. Kayama H, Takeda K. Regulation of intestinal homeostasis by innate and adaptive immunity. Int Immunol. 2012; 24:673-80.

4. van Lierop PP, Samsom JN, Escher JC, Nieuwenhuis EE. Role of the innate immune system in the pathogenesis of inflammatory bowel disease. J Pediatr Gastroenterol Nutr. 2009; 48:142-51.

5. Heinsbroek SE, Gordon S. The role of macrophages in inflammatory bowel diseases. Expert Rev Mol Med. 2009; 11:e14.

6. Steinbach EC, Plevy SE. The role of macrophages and dendritic cells in the initiation of inflammation in IBD. Inflamm Bowel Dis. 2014; 20:166-75.

7. Mahida YR. The key role of macrophages in the immunopathogenesis of inflammatory bowel disease. Inflamm Bowel Dis. 2000; 6:21-33.

8. Seo GS, Chae SC. Biological therapy for ulcerative colitis: an update. World J Gastroenterol. 2014; 20:13234-8.

9. Baumgart DC, Carding SR. Inflammatory bowel disease: cause and immunobiology. Lancet. 2007; 369:1627-40.

10. Lawrence $\mathrm{T}$. The nuclear factor NF- $\kappa \mathrm{B}$ pathway in inflammation. Cold Spring Harb Perspect Biol. 2009; $1: \mathrm{a} 001651$.
11. Bonizzi G, Karin M. The two NF- $\kappa$ B activation pathways and their role in innate and adaptive immunity. Trends Immunol. 2004; 25:280-8.

12. Yu H, Pardoll D, Jove R. STATs in cancer inflammation and immunity: a leading role for STAT3. Nat Rev Cancer. 2009; 9:798-809.

13. Atreya I, Atreya R, Neurath MF. NF- $\kappa B$ in inflammatory bowel disease. J Intern Med. 2008; 263:591-6.

14. Sugimoto K. Role of STAT3 in inflammatory bowel disease. World J Gastroenterol. 2008; 14:5110-4.

15. Feagins LA, Souza RF, Spechler SJ. Carcinogenesis in IBD: potential targets for the prevention of colorectal cancer. Nat Rev Gastroenterol Hepatol. 2009; 6:297-305.

16. Langmead L, Rampton DS. Review article: complementary and alternative therapies for inflammatory bowel disease. Aliment Pharmacol Ther. 2006; 23:341-9.

17. Jackson LN, Zhou Y, Qiu S, Wang Q, Evers BM. Alternative medicine products as a novel treatment strategy for inflammatory bowel disease. Am J Chin Med. 2008; $36: 953-65$.

18. Liu X, Wang J. Anti-inflammatory effects of iridoid glycosides fraction of Folium syringae leaves on TNBSinduced colitis in rats. J Ethnopharmacol. 2011; 133:780-7.

19. Huang YT, Wen CC, Chen YH, Huang WC, Huang LT, Lin WC, Arulselvan P, Liao JW, Lin SH, Hsiao PW, Kuo SC, Yang NS. Dietary uptake of Wedelia chinensis extract attenuates dextran sulfate sodium-induced colitis in mice. PLoS One. 2013; 8:e64152.

20. Guzman JR, Koo JS, Goldsmith JR, Muhlbauer M, Narula A, Jobin C. Oxymatrine prevents NF- $\kappa$ B nuclear translocation and ameliorates acute intestinal inflammation. Sci Rep. 2013; 3:1629.

21. Salaga M, Zatorski H, Sobczak M, Chen C, Fichna J. Chinese herbal medicines in the treatment of IBD and colorectal cancer: a review. Curr Treat Options Oncol. 2014; 15:405-20.

22. Yin F, Hu L, Lou F, Pan R. Dammarane-type glycosides from Gynostemma pentaphyllum. J Nat Prod. 2004; 67:942-52.

23. Liu X, Ye W, Mo Z, Yu B, Zhao S, Wu H, Che C, Jiang R, Mak TC, Hsiao WL. Five new Ocotillone-type saponins from Gynostemma pentaphyllum. J Nat Prod. 2004; 67:1147-51.

24. Liu X, Ye W, Mo Z, Yu B, Wu H, Zhao S, Che C, Hsiao WL. Three dammarane-type saponins from Gynostemma pentaphyllum. Planta Med. 2005; 71:880-4.

25. Attawish A, Chivapat S, Phadungpat S, Bansiddhi J, Techadamrongsin Y, Mitrijit O, Chaorai B, Chavalittumrong P. Chronic toxicity of Gynostemma pentaphyllum. Fitoterapia. 2004; 75:539-51.

26. Megalli S, Davies NM, Roufogalis BD. Antihyperlipidemic and hypoglycemic effects of Gynostemma pentaphyllum in the Zucker fatty rat. J Pharm Pharm Sci. 2006; 9:281-91. 
27. Circosta C, De Pasquale R, Occhiuto F. Cardiovascular effects of the aqueous extract of Gynostemma pentaphyllum Makino. Phytomedicine. 2005; 12:638-43.

28. Li L, Lau BHS. Protection of vascular endothelial cells from hydrogen peroxide-induced oxidant injury by gypenosides, saponins of Gynostemma pentaphyllum. Phytother Res. 1993; 7:299-304.

29. Li L, Jiao L, Lau BH. Protective effect of gypenosides against oxidative stress in phagocytes, vascular endothelial cells and liver microsomes. Cancer Biother. 1993; 8:263-72.

30. Conner EM, Grisham MB. Inflammation, free radicals, and antioxidants. Nutrition. 1996; 12:274-7.

31. Aktan F, Henness S, Roufogalis BD, Ammit AJ. Gypenosides derived from Gynostemma pentaphyllum suppress NO synthesis in murine macrophages by inhibiting iNOS enzymatic activity and attenuating NF- $\kappa \mathrm{B}-$-mediated iNOS protein expression. Nitric Oxide. 2003; 8:235-42.

32. Tai WC, Wong WY, Lee MM, Chan BD, Lu C, Hsiao WL. Mechanistic study of the anti-cancer effect of Gynostemma pentaphyllum saponins in the Apc(Min/+) mouse model. Proteomics. 2016; 16:1557-69.

33. Wirtz S, Neufert C, Weigmann B, Neurath MF. Chemically induced mouse models of intestinal inflammation. Nat Protoc. 2007; 2:541-6.

34. Pizarro TT, Cominelli F. Cytokine therapy for Crohn's disease: advances in translational research. Annu Rev Med. 2007; 58:433-44.

35. Dionne S, Laberge S, Deslandres C, Seidman EG. Modulation of cytokine release from colonic explants by bacterial antigens in inflammatory bowel disease. Clin Exp Immunol. 2003; 133:108-14.

36. Roda G, Marocchi M, Sartini A, Roda E. Cytokine Networks in Ulcerative Colitis. Ulcers. 2011; 2011:1-5.

37. Kornbluth A, Sachar DB, and Practice Parameters Committee of the American College of Gastroenterology. Ulcerative colitis practice guidelines in adults (update): American College of Gastroenterology, Practice Parameters Committee. Am J Gastroenterol. 2004; 99:1371-85.

38. Kozuch PL, Hanauer SB. Treatment of inflammatory bowel disease: a review of medical therapy. World J Gastroenterol. 2008; 14:354-77.

39. Hanauer SB. Review article: aminosalicylates in inflammatory bowel disease. Aliment Pharmacol Ther. 2004; 20:60-5.

40. Bruce ES. Inhibition of Interleukin-12 and/or -23 for the Treatment of Inflammatory Bowel Disease. Gastroenterol Hepatol (N Y). 2016; 12:784-6.
41. Bernstein CN. Treatment of IBD: where we are and where we are going. Am J Gastroenterol. 2015; 110:114-26.

42. Kolios G, Valatas V, Ward SG. Nitric oxide in inflammatory bowel disease: a universal messenger in an unsolved puzzle. Immunology. 2004; 113:427-37.

43. Xie QW, Kashiwabara Y, Nathan C. Role of transcription factor NF- $\mathrm{KB} / \mathrm{Rel}$ in induction of nitric oxide synthase. J Biol Chem. 1994; 269:4705-8.

44. Greten FR, Arkan MC, Bollrath J, Hsu LC, Goode J, Miething C, Goktuna SI, Neuenhahn M, Fierer J, Paxian $\mathrm{S}$, Van Rooijen N, Xu Y, O'Cain T, et al. NF- $\kappa \mathrm{B}$ is a negative regulator of IL-1 $\beta$ secretion as revealed by genetic and pharmacological inhibition of IKKbeta. Cell. 2007; 130:918-31.

45. Perse M, Cerar A. Dextran sodium sulphate colitis mouse model: traps and tricks. J Biomed Biotechnol. 2012; 2012:718617.

46. Sanchez-Munoz F, Dominguez-Lopez A, YamamotoFurusho JK. Role of cytokines in inflammatory bowel disease. World J Gastroenterol. 2008; 14:4280-8.

47. Xavier RJ, Podolsky DK. Unravelling the pathogenesis of inflammatory bowel disease. Nature. 2007; 448: 427-34.

48. Grivennikov SI, Greten FR, Karin M. Immunity, inflammation, and cancer. Cell. 2010; 140:883-99.

49. Aggarwal BB, Vijayalekshmi RV, Sung B. Targeting inflammatory pathways for prevention and therapy of cancer: short-term friend, long-term foe. Clin Cancer Res. 2009; 15:425-30.

50. Wong WY, Lee MM, Chan BD, Kam RK, Zhang G, Lu AP, Tai WC. Proteomic profiling of dextran sulfate sodium induced acute ulcerative colitis mice serum exosomes and their immunomodulatory impact on macrophages. Proteomics. 2016; 16:1131-45.

51. Qian Z, Wu Z, Huang L, Qiu H, Wang L, Li L, Yao L, Kang K, Qu J, Wu Y, Luo J, Liu JJ, Yang Y, et al. Mulberry fruit prevents LPS-induced NF- $\mathrm{B} / \mathrm{pERK} / \mathrm{MAPK}$ signals in macrophages and suppresses acute colitis and colorectal tumorigenesis in mice. Sci Rep. 2015; 5:17348.

52. Marín M, Maria Giner R, Rios JL, Recio MC. Intestinal anti-inflammatory activity of ellagic acid in the acute and chronic dextrane sulfate sodium models of mice colitis. $\mathrm{J}$ Ethnopharmacol. 2013; 150:925-34. 